\title{
Ways to make the West pay
}

Nairobi, Kenya

A CAMPAIGN to save the dwindling herds of African elephants may do more than protect an endangered species. For more than 100 scientists who met in Nairobi at the end of January, their wildlife conservation efforts are also teaching them how to play the funding game, Western-style.

The scientists arrived at a meeting sponsored by the United Nations Environmental Programme (UNEP) with hopes of tapping into some $\$ 300$ million that Western nations have made available for el-

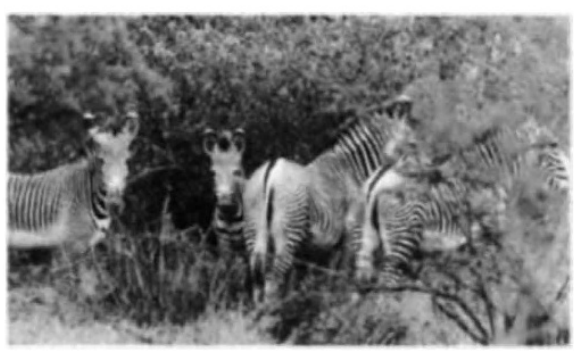

The Mpala Ranch in central Kenya is the latest example of international cooperation to preserve wildlife.

ephant conservation projects. Many expected to leave with money in hand. Instead, except for an announcement by the French government that it would immediately allocate $\$ 10$ million for regional conservation, what the scientists received was a better understanding of how to tailor their requests to satisfy their benefactors.

They learned, for example, that they must first do environmental impact studies of how their conservation efforts will affect the surrounding territory. They must show how their survival programmes will work in harmony with various rural development projects already under way. Finally, they must gain the support of their own governments for their plans.

"They must sort out how to present their proposals," says Mona Bjorkland, a senior programme officer for UNEP. "They have to formulate long-term and short-term objectives and justifications, and indicate clearly what they want to get out of the project. They also need a timetable, work plan and cost estimates."

Richard Leakey, director of the Kenya Wildlife Service, believes that success will come from cooperative ventures between African and Western nations. Although environmental officials acknowledge that the West must foot most of the bill, Leakey says that the two sides must be seen as equals if the ventures are to work smoothly.

"As an African country, you come from a position of weakness," he says. "Until African nations make science a higher priority, it will be difficult [for them] to gain an equal footing" in such cooperation ventures.
Leakey says that a proposal to provide money for environmental impact studies as part of other grants made to the developing world will be presented at the United Nations' Earth Summit in Rio de Janeiro this summer. African scientists will find it easier to compete for international funding if these statements are part of their proposals, he says.

Their requests must also be submitted in language that donors are accustomed to reading, says Bjorklund, and channelled through the appropriate embassies or through such multinational organizations as the World Bank, UNESCO or the Food and Agriculture Organization.

They must also persuade their own governments to support them. Wildlife preservation has an understandably low priority in countries faced with such staggering problems as widespread disease, high illiteracy rates, inequitable distribution of land and a lack of food and water. One strategy that might appeal to financially strapped governments is to look at wildlife as a legitimate natural resource that can attract outside investors, says Mark Stanley Price, director of African operations for the African Wildlife Foundation in Nairobi. If properly cared for, he says, wildlife also has the advantage of being a renewable resource.

Perhaps the most unpleasant lesson that the African scientists learned at the meeting was that the funding process can take months or even years. It is unlikely that they will see any of the $\$ 305$ million that they have requested, for some 325 projects, before the end of the year. "You can't expect a different set of rules just because it involves elephants," says Price.

A case in point was Leakey's plea at the meeting for surplus material from the United States as it dismantles its military forces in Europe and elsewhere around the world. A representative from the US Fish and Wildlife Service, Ken Stansell, says that his government is more than willing to provide such material as it becomes available, but that there are many requests for it from humanitarian groups as well as from conservationists. In 1990 wildlife officials even convinced Congress to add environmental purposes to the list of acceptable uses of such excess military equipment, he says, and last spring 41 pickup trucks, ten years old but still in working order, were sent by barge to eight African countries after US forces in Germany no longer needed them.

"We have requests in the millions of dollars for this material", says Stansell. "And even though the articles themselves are free, somebody has to pay for whatever repairs, maintenance and shipping costs are incurred."

Jane Stevens

\section{Wellcome diversifies} London

BRITAIN's largest charitable research foundation, the Wellcome Trust, has decided to sell a large proportion of its 73.6 per cent holding in the drugs company Wellcome plc.

The Trust's move to diversify its assets should provide a short-term boost to its spending on medical research. Even more significantly, the diversification will protect the trust's income from harm if the stock price of the pharmaceutical company drops suddenly. The Trust, which will spend some $£ 80$ million on medical research in 1991-92, is the second largest source of funds for British academic biomedical researchers, lagging only behind the government funded Medical Research Council (MRC).

Ninety six per cent of the Wellcome Trust's income comes from its holding in Wellcome plc. "We've got all our eggs in one basket," says Bridget Ogilvie, director of the Trust. "No matter how good that basket is" at present, she says, diversification is essential to guarantee the Trust's future income.

Although Wellcome plc is currently performing well, Ogilvie is well aware of the potential hazards if a charitable foundation fails to spread its assets over a range of quoted companies. "Everyone in Britain knows what happened to Nuffield," she says. Her reference is to the Nuffield Foundation, which saw its income reduced by almost 90 per cent in the early 1970 s as its shares in the British Leyland motor company plummeted in value.

If the Wellcome Trust suffered a similar decline in income to that experienced by Nuffield, the consequences for British medical research would be disastrous. Unlike the other UK charitable foundations that live off an invested endowment, the Wellcome Trust's spending is almost entirely concentrated on medical research.

Wellcome's trustees want to reduce the Trust's holding in Wellcome plc to between 25 and 50 per cent of the company's shares. This will need court permission, as the will of Sir Henry Wellcome and rules drawn up by the Charity Commissioners stipulate that the Trust must retain at least a 50 per cent holding. But Ogilvie says that the trustees have taken soundings, and do not expect their plan to meet any serious obstacles.

In addition to long-term security, the sale will also provide a short-term boost to the Trust's spending on medical research. Ogilvie expects to realise about $£ 35$ million in income for each $£ 1,000$ million of Wellcome plc shares sold. If the Trust reduced its Wellcome plc holding to 25 per cent, it would have to sell more than $£ 4,500$ million worth of shares.

Peter Aldhous 